DANIEL KUKLA

WIOLETA DUDA

Akademia im. Jana Dtugosza w Częstochowie

\title{
DORADZTWO ZAWODOWE JAKO ATRYBUT W PROCESIE WKRACZANIA WSPÓŁCZESNEJ MLODZIEŻY NA RYNEK PRACY
}

\section{JOB ADVICE AS AN ATTRIBUTE OF THE INTRODUCTION OF YOUTH INTO THE JOB MARKET}

\section{Streszczenie}

Bardzo często ludzie traktują okres studiów jako czas przedłużający ich młodość, czas dobrej zabawy, w którym nie ma miejsca na podejmowanie istotnych decyzji zawodowych. Wybór kierunku studiów, szczególnie w obecnym systemie nie jest wiążący i jednoznaczny z wykonywaniem wyuczonego zawodu. Planowanie przyszłej drogi zawodowej powinno się rozpocząć właśnie w okresie studiów. Jest to bowiem czas na wieloaspektowy rozwój, zarówno zdobywanie specjalistycznej wiedzy z określonego obszaru, jak i pierwszych doświadczeń zawodowych. Studia dają szansę na pozaprogramowe formy kształcenia oraz korzystanie z usług Akademickich Biur Karier, dzięki którym rozwijamy własne umiejętności oraz wyznaczamy płaszczyzny, w których dobrze się czujemy.

Wielu absolwentów studiów wyższych niezależnie od studiowanego kierunku boryka się z brakiem umiejętności i wykorzystania zdobytej wiedzy w praktyce. Niedoprecyzowanie planów i perspektywy na przyszłość, odwlekanie decyzji zawodowych, roszczeniowa postawa wobec 
otoczenia to najczęstsze problemy absolwentów, którzy wkraczają na rynek pracy. Pojawia się tutaj konieczność pomocy doradcy zawodowego, którzy poprzez działania doradcze jest w stanie pomóc odnaleźć młodemu człowiekowi właściwą drogę. Studenci i absolwenci nie wiedzą gdzie można znaleźć pracę zgodną ze zdobywanym wykształceniem, jak jej szukać, jakie firmy z danej branży funkcjonują na lokalnym czy ogólnopolskim rynku pracy. To brak podstawowych informacji z zakresu świata zawodów, funkcjonowania rynku pracy są przyczynami niedostosowania się absolwentów do istniejących realiów.

Przejście między edukacją i wejście w świat pracy jest trudne, szczególnie dla absolwentów nie mających odpowiedniego przygotowania z zakresu poruszania się po rynku pracy. Wykształcenie nie jest obecnie gwarancją uzyskania zatrudnienia, a wymagający pracodawcy oprócz dyplomu oczekują umiejętności, które warto zdobywać właśnie w okresie studiów.

\section{Słowa kluczowe}

Doradztwo zawodowe, student, absolwent, rynek pracy, Akademickie Biuro Karier.

\section{Summary}

Very often young people view their time of study as a period where they can prolong their youth and engage in fun, rather than as the time of taking important decisions regarding future career. The choice of study in our present system is not necessarily connected with future profession. However, planning for a future profession should begin during the time of study because it is the time of greater perspectives both in terms of specialised knowledge and work experiences. Study provides different forms of educational experience and access to Career Services, thanks to which students can develop their own abilities and can find areas suitable to them.

Many graduates of Higher Education, regardless of their studies, have problems with utilising their knowledge in practice. The most frequent issues of graduates entering the job market are: imprecise plans for the 
future; ignoring final decisions about professional development; the attitude that they should be given everything. There is a need here for the assistance of the career advisor to help the young person find the right path. Graduates lack the knowledge of where and how to find a job connected to their field of education, both in a local and national perspective. The lack of basic information on the functioning of the job market and which jobs are available cause the graduates to not realise their potential.

The transition between education and the world of work is difficult, but even more so for those who lack the basic information of how to cope with the change. In today's world, education itself is not a guarantee for obtaining a job as demanding employees expect not only a diploma but also experience gained during study.

\section{Key words}

Job advice, student, graduate, job market, Career Service Advisors.

\section{WPROWADZENIE}

Świat, w którym żyjemy, nieustannie się zmienia. Nowe odkrycia, wynalazki, systemy wartości wpływają na jakość naszej egzystencji. Obserwowalny postęp naukowo-techniczny wywołuje zmiany we wszystkich sferach życia. Przeobrażeniu ulegają nasze postawy, styl życia oraz przebieg życia zawodowego. Wielu badaczy uważa, że w wyniku postępującego procesu industrializacji zmniejszy się ogólne zapotrzebowanie na siłę robocza, bo znaczna część wykonywanych dotychczas przez ludzi zadań przejmą maszyny. Mówi się nawet o końcu pracy. Podejmując jakiekolwiek decyzje zawodowe lub uczestnicząc już w kształceniu, należy mieć na uwadze tendencje panujące na rynku pracy oraz popyt na określone zawody i w określonych branżach. Także postępujący proces globalizacji wpływa istotnie na pracowników oraz warunki pracy i zatrudnienia. Można stwierdzić, że rynek pracy, pracodawcy wciąż podnoszą poprzeczkę dla następnych pokoleń - przede wszystkim ab- 
solwentów. Należy także podkreślić, że rynkiem pracy rządzi konkurencja i należy się do niej przyzwyczaić.

Zmienia się również nasze prawo pracy, struktura zatrudnienia, inne są oczekiwania pracodawców względem pracowników. Sytuacja demograficzna i wdrażanie w naszym kraju licznych reform gospodarczych wpływają na wielkość i jakość kapitału ludzkiego, który jest podstawowym ogniem twórczym w gospodarce rynkowej. Wszystkie powyższe czynniki mają wpływ na rynek pracy, który w dużym stopniu determinuje strukturę zawodów. Przyszłość postrzegana jest nie jako czas sukcesów zawodowych i robienia kariery, ale jako czas niepewności i zagrożeń społecznych. ${ }^{1}$ Tylko obranie dobrej drogi zawodowej może tę niepewność zniwelować. Zmiany w sposobie organizacji i funkcjonowania przedsiębiorstw, zmiany w sposobie wytwarzania dóbr, zmiany w zachowaniu jednostek w sposób istotny wpływają na decyzje zawodowe człowieka. ${ }^{2}$ Nie jest to już proces jednorazowy, oczywisty i przewidywalny. Każda osoba kończąca studia musi być przygotowana nie tylko na aktywne poszukiwanie zatrudnienia, ale także na to iż nie będzie to stałe miejsce pracy.

Wkroczenie absolwentów na rynek pracy jest nie tylko w obecnej rzeczywistości gospodarczej bardzo trudne, ale jednocześnie ważne, jak to się odbędzie. Praca zawodowa towarzyszy człowiekowi przez bardzo dużą cześć życia. Istotne zatem staje się, aby ta pierwsza praca - nieistotne, czy rozpoczynamy ją po skończeniu studiów, czy też w czasie ich trwania - była dla młodego człowieka pewnym wyzwaniem, wnosiła nowe doświadczenia. Satysfakcja i zadowolenie z pierwszej pracy często wpływają na dalszą drogę zawodową jednostki. Czas studiów to czas zdobywania wiedzy, praktyki i zgłębiania określonej dziedziny. Ale w obecnej sytuacji na rynku pracy to również czas przemyślenia drogi zawodowej, zaplanowania swojej przyszłości, wyznaczenia długofalowych celów. To niezwykle ważne, aby przejście od edukacji do pracy

\footnotetext{
1 J. Fitoussi, Czas nowych nierówności, Kraków 2000, s. 22.

2 K. Lelińska, Znaczenie socjologicznych teorii wyboru zawodu w pracy doradcy zawodowego, [w:] H. Bednarczyk, J. Figurski, M. Żurek, Pedagogika pracy. Doradztwo zawodowe, Radom 2002, s. 124.
} 
było jak najmniej stresujące, aby młody absolwent nie zasilił szeregu osób bezrobotnych. Studia dają możliwość bliższego poznania świata pracy, określonych zawodów, eksperymentowania. Ważne jest również obecnie coraz częstsze kładzenie nacisku na orientacje zawodową, również w czasie studiów.

Wybory, jakich dokonuje każdy człowiek, wpływają i kreująjego karierę zawodową. Nie odbywa się to w krótkim czasie, ale ma charakter dynamiczny, składających się z kilku etapów. Ważne, aby jednostka nie pozostała sama, bez odpowiednich i potrzebnych informacji, kiedy podejmuje wybory edukacyjno-zawodowe. Proces orientacji zawodowej rozpoczyna się już od najmłodszych lat i trwa całe życie. Nikt nie jest w stanie przewidzieć, jak będzie wyglądał rynek pracy za kilka lat, ale cele są konieczne do wyznaczenia.

Warto, aby każdy kto jest w sytuacji podejmowania decyzji zawodowych dążył do tego, aby były one spójne z wyznawanymi wartościami, preferencjami, oraz celami osobistymi i rodzinnymi. ${ }^{3} \mathrm{~W}$ naszym kraju mamy obecnie dynamiczny wzrost osób studiujących oraz osób kończących studia. Na rynek pracy wkraczają jednostki o zróżnicowanych kwalifikacjach, z dyplomami różnych uczelni i różnych kierunkach. Nie każdy jednak ma możliwość podjęcia prac w wyuczonym zawodzie, nie każdy może znaleźć pracę. Stąd też wzrasta potrzeba pomocy dla studentów, aby bardziej płynnie przeszli od edukacji do pracy. Ważne na tym etapie stają się usługi poradnictwa zawodowego, doradcy, który zajmie się: wsparciem klienta - nawiązaniem, podtrzymaniem relacji, komunikacja; wysłuchaniem klienta; towarzyszeniem; pytaniem, zdobywaniem i analizowaniem informacji o kliencie; określeniem potrzeb klienta; rozpoznaniem problemów klienta; pobudzaniem do refleksji i myślenia; pomocą w rozpoznaniu, analizie umiejętności, predyspozycji i zainteresowań klienta; pomocą w artykulacji mocnych i słabych stron; wskazywaniem źródeł informacji dotyczących rynku pracy i rynku edukacyjnego; udzielaniem, przekazywaniem informacji, wskazywaniem źródeł informacji; wsparciem klienta w wyborach edukacyjnych

${ }^{3}$ Por. M. Mrozek, Praca z klientem dorostym, Warszawa 2009, s. 7. 
i zawodowych; ukierunkowaniem, omówieniem alternatyw; wsparciem przy wytyczaniu celów i planów działania; wzmocnieniem wiary klienta w swoje możliwości, motywowanie (na podstawie konkretnych uzyskanych od klienta informacji); współpracą z instytucjami, odesłaniem do instytucji specjalistycznych. ${ }^{4}$

Każde z tych działań jest niezwykle istotne również w przypadku studentów. Doradztwo zawodowe powinno im towarzyszyć podczas studiowania oraz kiedy wkraczają na rynek pracy. Szczególnie, że obecnie kontakt z profesjonalnym doradcą zawodowym jest znacznie łatwiejszy i prostszy. Specjalistów z tego zakresu możemy spotkać nie tylko w publicznych służbach zatrudnienia, ale również na uczelniach, w Biurach Karier czy w prywatnych instytucjach.

Współcześni młodzi ludzie mają pełną świadomość, jakie znaczenia odgrywa podczas poszukiwania pracy wyższe wykształcenie, wiedza i umiejętności zdobyte na studiach, zwłaszcza w czasach kryzysu, dlatego też tak licznie studiują zarówno na uczelniach technicznych, jak i humanistycznych, chcąc w ten sposób zwiększyć swoje szanse na rynku pracy. Młodzi ludzie, absolwenci uczelni wyższych stanowią ważny segment szeroko pojętego rynku pracy. W momencie, kiedy osiagną oni już odpowiedni poziom wykształcenia, rozpoczynają poszukiwanie zatrudnienia, zaczyna się dla nich kolejny ważny okres w życiu - etap życia zawodowego.

Rolą współczesnej edukacji na wszystkich poziomach nauczania jest kreowanie społeczeństwa informacyjnego, to znaczy społeczeństwa wiedzy, potrafiącego twórczo przeobrażać zdobytą informację w kreatywną postawę na konkurencyjnym i globalnym rynku. Celem edukacji powinno być wyposażenie w podstawy wiedzy ogólnej, umożliwiające sprawne funkcjonowanie we współczesnym globalnym społeczeństwie, ale także zdobycie zawodu a tym samym znalezienie zatrudnienia. W zmieniających się warunkach życia społeczno-gospodarczego kraju szkolnictwo wyższe ma obowiązek przygotowywać kadry o najwyższych kwalifikacjach.

\footnotetext{
${ }^{4}$ Por. D. Pisula, Poradnictwo kariery przez całe życie, Warszawa 2009, s. 19.
} 
Podjęcie pracy w czasie lub po ukończeniu edukacji stanowi pierwszy, znaczący krok w życiu zawodowym młodego człowieka. Poszukiwanie pierwszej pracy to szczególny okres w jego życiu; w tym czasie dokonuje się bowiem konfrontacja wyobrażeń i oczekiwań związanych z przyszłą praca, z realiami panującymi na rynku zatrudnienia. Jednakże procesy przekształceń gospodarczych mających miejsce na przełomie XX i XXI wieku i związane z nimi istotne zmiany na rynku pracy i w szeroko pojmowanej sferze zatrudnienia spowodowały, że bardzo wiele młodych osób znalazło się w nowej, radykalnie zmienionej sytuacji życiowej. Problem ten dotyczy, niestety, również tych, którzy posiadają odpowiednie kwalifikacje i wyższe wykształcenie.

\section{RYNEK PRACY A SZANSE MLODZIEŻY NA ZNALEZIENIE ZATRUDNIENIA}

Rynek pracy to specyficzna sfera rzeczywistości, na której dochodzi do spotkania osoby, która sprzedaje i która kupuje pracę, czyli pracodawcy i pracownika, a praca jest tu towarem. Ale należy zaznaczyć, że praca dla każdego człowieka to coś więcej. To nie tylko towar, który sprzedajemy, to dla większości samorealizacja oraz możliwość wykazania się. Jak podkreślał Jan Paweł II pracę człowieka należy uznać za swoistego rodzaju powołanie - „Stworzony bowiem na obraz i podobieństwo Boga Samego (por. Rdz 1, 26) wśród widzialnego wszechświata, ustanowiony, aby ziemię czynić sobie poddaną (por. Rdz 1, 28), jest człowiek przez to samo od początku powołany do pracy. Praca wyróżnia go wśród reszty stworzeń, których działalności związanej z utrzymaniem życia nie można nazywać pracą - tylko człowiek jest do niej zdolny i tylko człowiek ją wykonuje, wypełniając równocześnie pracą swoje bytowanie na ziemi. Tak więc praca nosi na sobie szczególne znamię człowieka i człowieczeństwa, znamię osoby działającej we wspólnocie osób - a znamię to stanowi jej wewnętrzną kwalifikację, konstytuuje niejako samą jej naturę". ${ }^{5}$ Podążając za Zygmuntem

5 Jan Paweł II, Laborem Exercens, Lublin 1986, s. 7. 
Wiatrowskim, należy stwierdzić, że rola pracy w życiu współczesnego człowieka jest ogromna. Stanowi ona niezbędny warunek egzystencji, wyznacznik miejsca człowieka w społeczeństwie, czynnik kształtujący osobowość, wpływa na fizyczny rozwój człowieka, wyzwala w nim inicjatywę i twórczą aktywność myślową, dostarcza przeżyć estetycznych, przynosi radość i zadowolenie. ${ }^{6}$ Tak istotne staje się zatem, aby każdy młody człowiek znalazł swoje miejsce w świecie pracy, która tyle wnosi do naszego życia. Miejsce na rynku pracy może odnaleźć każdy pod warunkiem aktywnego i umiejętnego jego poszukiwania.

Warto wspomnieć krótko o najważniejszych zmianach na rynku pracy. Należą do nich:

- zanikanie wielkich przedsiębiorstw, korporacji na rzecz tzw. przedsiębiorstwa z wysoko wykwalifikowanymi pracownikami, gdzie celem jest sprzedaż wiedzy i gdzie do pracy nad konkretnym zadaniem tworzone są grupy celowe,

- uelastycznienie rynku pracy (ruchome płace - zależne od rynku pracy, indywidualizacja umów o pracę),

- wzrost merytokracji - zależności między liczbą lat nauki a wynagrodzeniem,

- powstawanie popytu na pracę o charakterze i zasięgu ponadnarodowym (jako efekt globalizacji); wiąże się $\mathrm{z}$ tym tania siła robocza w krajach słabo rozwiniętych,

- elastyczne zatrudnienie, elastyczne formy pracy: umowy na czas określony, umowy „do projektu”, praca dorywcza, outsourcing (wypożyczanie pracowników),

- telepraca - świadczenie pracy na odległość (efekt rewolucji informatycznej).

1. praca czasowa - nowoczesne korporacje mogą posiadać stosunkowo niewielki stały personel. Na ich obrzeżach działają firmy lub pracownicy angażowani jedynie do wykonania określonych czynności lub usług. Wiąże się to nieodłącznie z rozpowszechnieniem się outsourcingu, który sprawia, że zatrudnienie przyjmuje coraz częściej formy

\footnotetext{
${ }^{6}$ Por. Z. Wiatrowski, Podstawy pedagogiki pracy, Bydgoszcz 1994, s. 25.
} 
pracy sezonowej/zadaniowej. W związku z tym ważną cechą tworzącego się w dobie globalizacji rynku pracy jest dualizm: zmniejszającej się liczbie ludzi zatrudnionych towarzyszy zwiększająca się liczba osób nie mających stałego zajęcia i oczekujących na pracę.

2. praca nakładcza - praca nakładcza (chałupnictwo) polega na wytwarzaniu przez wykonawcę przedmiotów lub ich części z powierzonego materiału lub świadczeniu usług na polecenie i rachunek zlecającego. Rozpowszechnienie się pracy nakładczej w dłuższym okresie może wpływać destabilizująco na lokalny rynek pracy, ponieważ oznacza wzmocnienie nad nim kontroli korporacji transnarodowych.

3. leasing pracowniczy - organizowaniem leasingu pracowniczego zajmują się agencje pracy tymczasowej. Daje on pracodawcy możliwość zatrudniania pracowników w zależności od pojawiających się potrzeb personalnych. Podobnie jak praca nakładcza wpływa na destabilizację rynku pracy. ${ }^{7}$

Zachodzące zmiany i tendencje wpływają zarówno na warunki pracy, jak i poszukiwanie zatrudnienia. Nowe formy zatrudnienia wymagają większej elastyczności, ale przede wszystkim nie zaspokajają potrzeby bezpieczeństwa, stąd też zapewne nie każdy człowiek chce zaryzykować. Należy uczyć się elastyczności, mobilności i przyzwyczaić do zmiany zatrudnienia kilka razy w czasie kariery zawodowej.

Wszystkie powyższe czynniki mają istotny wpływ na przebieg kariery zawodowej oraz dokonywanie wyboru zawodu. Dlatego też niezbędna staje się interwencja i pomoc doradcy zawodowego. Współpraca z doradcą zawodowym nikomu nie gwarantuje znalezienia lub utrzymania zatrudnienia. Stwarza jedynie możliwości, wskazuje kierunki dalszej, systematycznej pracy. Dzięki poradnictwu jednostka dociera do informacji, których bez wsparcia doradczego nie umiałaby znaleźć i - co równie istotne - zrozumieć, a następnie skutecznie wykorzystać. Szczególnie jest to możliwe właśnie w obecnej sytuacji, kiedy usługi doradcze są coraz łatwiej dostępne i stają się bardziej powszechne.

\footnotetext{
${ }^{7}$ Por. M. Eggert, Doskonała kariera, Poznań 2004, s. 23-28.
} 
Szeroko dostrzegalne są zmiany zarówno na polskim, jak i europejskim rynku pracy, a co się z tym wiąże - również zmiany dotyczące pozycji i roli pracownika. Proces postępu technicznego, rozwój technologii informatycznych, procesy globalizacji, przekraczanie barier geograficznych i politycznych w działalności gospodarczej - wszystkie te zjawiska powodują deregulacje gospodarki i rynku pracy oraz wyznaczają nowe wyzwania zarówno dla osób podejmujących pracę, jak i próbujących wejść na rynek. Nowe wyzwania przed osobami wkraczającymi na rynek pracy wiążą się nie tylko z nowymi technologiami, większymi wymaganiami stawianymi pracownikom, ale również z niepewnością dotycząca przyszłości pracy, miejsca pracy, umowy o pracę. Wysokie wymagania pracodawców, duża konkurencja na rynku pracy oraz coraz większa elastyczność form zatrudnienia powodują, że decyzję o uzupełnieniu kwalifikacji, podjęciu dalszego kształcenia, zaczęły podejmować osoby dojrzałe zawodowo, posiadające już doświadczenia związane z pracą. Przez wiele lat w Polsce przebieg życia zawodowego był możliwy do przewidzenia. Można było zaplanować ukończenie szkoły, studiów, nabycie umiejętności w danej branży, w kolejnym etapie kariery objęcie stanowisk specjalistycznych, czy też kierowniczych. Współczesne kariery nie przebiegają w tak regularny sposób. Coraz bardziej zależą od zdolności przystosowywania się do zmieniającego się rynku, a także gotowości do podejmowania pracy w nowych organizacjach i branżach. Usługi w zakresie poradnictwa zawodowego są potrzebne już nie tylko na etapie wyboru zawodu w gimnazjum czy w szkole średniej, ale także coraz częściej wsparcia i pomocy w zakresie podejmowanych decyzji zawodowych poszukują właśnie osoby dorosłe. ${ }^{8}$ Studenci opuszczający mury uczelni muszą być przygotowani, że wyuczony zawód, zdobycie dyplomu to dopiero początek ich drogi, ich kariery, to czasami dopiero początek edukacji. Kwalifikacje uzyskane dziś już za parę lat mogą ulec deklasacji i konieczne będzie ich podnoszenie lub całkowity proces reorientacji zawodowej.

Kariera zawodowa wypełnia większość życia jednostki. Coraz ważniejsze stają się dla człowieka wybory, jakich dokonuje, a które dotyczą

${ }^{8}$ Por. M. Mrozek, Praca z klientem dorostym, Warszawa 2009, s. 7. 
drogi zawodowej. Ważne jest, aby kariera zawodowa dawała jednostce coś więcej niż materialne korzyści. Na rynku pracy i w sferach z nim związanych dzieją się dynamiczne zmiany, zmienia się prawo pracy, struktura zatrudnienia, inne są też oczekiwania pracodawców względem pracowników i wobec tych zmian nie jest sprawą prostą wybrać właściwą drogę realizacji kariery zawodowej. Rozwój usług doradczych jest jednym z wielu rozwiązań, aby ułatwić człowiekowi płynne przechodzenie przez wszystkie etapy. Kariera zawodowa nie powinna być sposobem na życie, a jedynie dodatkiem.

Bardzo istotnym czynnikiem jest poznanie aktualnych tendencji na rynku pracy, które ostatnio bardzo często się zmieniają. Musimy, bowiem wiedzieć:

1. czy dostaniemy pracę w wybranym przez siebie zawodzie (ewentualnie, gdzie tę pracę dostaniemy, co może się wiązać z wyjazdem);

2. jak się kształcić, aby zwiększyć swoje szanse na zatrudnienie;

3. jakie cechy i umiejętności są najbardziej pożądane na rynku pracy;

4. jakie zawody są zanikające;

5. jakie zawody są zawodami przyszłości;

6. jaki jest nasz lokalny rynek pracy;

7. jak wygląda sytuacja na polskim oraz europejskim rynku pracy.

Odpowiedzi na te pytania są niezbędne, gdy wkraczamy na rynek pracy. Szybkie zmiany gospodarcze wymagają częstego przystosowywania się do zaistniałych sytuacji. Aby to wszystko osiagnąć, należy dokonywać dobrych i trafnych wyborów zawodowych. Nie jest to łatwe warunkach współczesnej rzeczywistość. Ciagle zmiany, otwarcie się Polski na Europę, coraz większy napływ siły roboczej do naszego kraju z zewnątrz, sprawiają że wiele osób czuje się zagubionych. Nie są to już czasy, gdy wyuczony zawód dawał nam możliwość pracy na całe życie. Nie możemy również zawsze liczyć na to, iż to właśnie w Polsce znajdziemy zatrudnienie. To elastyczność, mobilność i otwartość na zmiany mogą nam zapewnić zatrudnienie i pomoc w znalezieniu odpowiedniej pracy. Jeśli więc mówimy o funkcjonowaniu poradnictwa zawodowego w warunkach społecznej gospodarki rynkowej, to przede wszystkim trzeba podkreślić jej nowe cele. Tymi celami na pewno jest zaspokajanie 
potrzeb klientów, którzy coraz częściej, niezależnie od wieku potrzebują informacji i porad niezbędnych do zaplanowania swojej kariery zawodowej.

Planowanie kariery może odbywać się już w wymiarze nie tylko lokalnym, ale globalnym, transnarodowym, transkulturowym, nawet wielokulturowym. ${ }^{9}$ Młode osoby muszą być przygotowane na pracę zarówno w naszym kraju, jak i w całej Europie. Proces globalizacji będzie postępował i należy być przygotowanym do pracy na rynku międzynarodowym.

Przeobrażenia warunków życia stawiają przed współczesnym człowiekiem rozliczne utrudnienia, a jednocześnie kształtują nowy model życia (bycia) człowieka. Ponieważ wymagania ery globalizacji stawiane współczesnemu człowiekowi są bardzo wygórowane, toteż „globalny człowiek" wobec tych wszystkich wymagań oczekuje od różnych instytucji doradczych - pomocy w przygotowaniu się do nowego życia i ukształtowania w nim umiejętności adaptacji w nieustannie zmieniających się warunkach. W tym „nowym” świecie każda jednostka jest swego rodzaju ,indywiduum” które oczekuje za każdym razem czegoś nowego, wartościowego od potencjalnego doradcy. Ponieważ konfrontacja z realiami współczesności nie należy do łatwych (rodzi bowiem obawy nieporadzenia sobie z własnymi problemami) - toteż daje się zauważyć że w tym globalnym świecie „utrzymuje się wysoka koniunktura na porady (...)." ${ }^{10}$ Młode osoby, które kończą studia, nagle z miesiąca na miesiąc przestają być studentami i wkraczają w dorosłe życie, czasami bez doświadczenia, ale z wielkimi marzeniami. Po latach trudu, który każdy wkłada we własną edukację, są nierzadko duże oczekiwania. Niestety, współczesny rynek pracy nie zawsze daje szansę nawet najlepszym absolwentom. Trzeba o tę szansę nierzadko powalczyć.

Zmiany zachodzące $\mathrm{w}$ dzisiejszym świecie, związane $\mathrm{z}$ konkurencją, nowymi technologiami, globalizacją sprawiają, że osoby, które chca utrzymać się i rozwijać na rynku pracy, muszą planować i kształtować

\footnotetext{
9 A. Bańka, Poradnictwo transnacjonalne, Warszawa 2006, s. 37.

${ }_{10}$ U. Beck, Spoleczeństwo ryzyka - w drodze do innej nowoczesności, Warszawa 2004, s. 12.
} 
swój rozwój zawodowy od samego początku wstapienia na ścieżkę zawodową. W czasach, gdy najpopularniejszymi słowami na rynku pracy są: mobilność, elastyczność, przekwalifikowanie się, nie można mówić o tradycyjnym ,przypisywaniu” na stałe osoby do konkretnej branży. Kluczem do sukcesu są umiejętności, rozległe kwalifikacje i świadome oraz dojrzałe budowanie swojej drogi zawodowej. Ludzie pytani o to, czym kierują się przy wyborze miejsca pracy, najczęściej wybierają satysfakcję z wykonywanego zawodu oraz dobrą atmosferę. Wynika $\mathrm{z}$ tego, że potrzebę stabilności wyprzedziła chęć zarabiania dużych pieniędzy i otrzymywania bogatego pakietu socjalnego. ${ }^{11}$

Praca zawodowa, rozwój zawodowy są niezwykle istotne w życiu każdej jednostki. Praca to forma wyrażania siebie, realizacji własnych wizji, pomysłów, potrzeb. To praca dostarcza sukcesów, czasem porażek, ale zawsze informacji zwrotnych o samym sobie. Warto zatem powalczyć o własne miejsce w świecie pracy.

Problemy zatrudnienia młodych osób, absolwentów zostały również zauważone przez Unię Europejską. Polska jako kraj członkowski Unii Europejskiej opracowała tzw.: „Strategię Państwa dla Młodzieży na lata 2003-2012", którą z czasem rozbudowano i uzupełniono o kolejne wpisy, tworząc „Strategię Państwa dla Młodzieży na lata 2006-2012”. Polityka dla młodzieży, skierowana jest do ludzi od 15 do 25 roku życia. W Polsce wymieniona grupa stanowi 16,8\% ogółu Polaków, co daje liczbę $6,5 \mathrm{mln}$ osób. Wspomnianą grupę docelową tworzą uczniowie, studenci, absolwenci, bezrobotni, samotne matki, młodzież niepełnosprawna, młodzi ludzie żyjący na granicy prawa, młodzież mieszkająca na wsi lub w mieście. Widać z tego wyraźnie jak bardzo różnorodną grupę stanowią młodzi ludzie w Polsce i jak wiele różnorodnej pomocy potrzebują.

Powyższy dokument powstał w 2002 roku, został opracowany przez Ministerstwo Edukacji Narodowej i Sportu, z uwzględnieniem zapisów Białej Księgi Komisji Europejskiej - Nowe impulsy dla młodzieży europejskiej. Głównym celem, jaki wyznaczył sobie nasz kraj we wspo-

11 Strona internetowa www.praca.pl, stan na: 15.03.2010. 
mnianej Strategii, jest wyrównywanie szans rozwoju młodych Polaków. Państwo stawia również na aktywizację młodego pokolenia i rozwijania jego aktywności społecznych. Kluczowymi segmentami Strategii są: edukacja młodzieży, zatrudnienie, uczestnictwo młodzieży w życiu publicznym, czas wolny, sport, turystyka, zdrowie i profilaktyka. ${ }^{12}$

Zatrudnienie, szeroko pojmowana tematyka rynku pracy, stanowi jeden z kluczowych trzonów Strategii, dlatego, iż poziom bezrobocia młodzieży jest coraz wyższy i stał się zjawiskiem niepokojącym. Państwo politykę zatrudnienia kieruje do absolwentów uczelni wyższych, jak również do młodzieży, która porzuciła dalszą edukację oraz młodych ludzi długotrwale bezrobotnych. Głównym problemem, na który napotykają młodzi, jest brak płynności na rynku pracy oraz problemy ze znalezieniem pierwszego zatrudnienia. Aby zapobiegać takim zjawiskom, państwo tworzy programy pomocowe, stawia na promocję przedsiębiorczości, namawia do zakładania własnych firm, tworzenia nowych miejsc pracy. Ważnym działaniem jest zachęcanie pracodawców do tworzenia nowych etatów oraz elastycznych form zatrudniania młodzieży, aby stworzyć możliwość zdobycia pierwszego doświadczenia zawodowego, które jest tak cenne w dzisiejszych czasach. Szczególna uwaga zwracana jest również na odpowiednie dopasowanie edukacji zawodowej do wymagań współczesnego rynku pracy. ${ }^{13}$

\section{ZNACZENIE AKADEMICKICH BIUR KARIER}

Obok pozyskiwania wiedzy i praktycznych umiejętności, studia to obecnie czas na odbywanie praktyk, staży, wolontariatu oraz podnoszenia kwalifikacji i kompetencji poprzez uczestnictwo w dodatkowych szkoleniach, warsztatach czy kursach. Wszystko to znacznie podnosi wartość absolwenta na rynku pracy i zwiększa jego szanse na znalezienie zatrudnienia. W tym miejscu pojawia się rosnąca we współczesnych czasach rola Akademickich Biur Karier (ABK) jako jednego ze źródeł

12 B. Fatyga, Biała księga młodzieży polskiej. Diagnoza sytuacji młodych Polaków jako podstawa strategii państwa dla młodzieży, Warszawa 2004, s. 59.

${ }^{13}$ D. Walczak-Duraj, Wartości i postawy młodzieży polskiej, Łódź 2009, t. II, s. 72-76. 
nie tylko zdobywania pracy, ale również uczenia się, w jaki sposób podejść do jej poszukiwania, jak wykorzystywać swoje atuty i jakie metody mogą okazać się najskuteczniejsze w zdobyciu wymarzonego etatu.

Zgodnie z ustawą z 20 kwietnia 2004 roku o promocji zatrudnienia i instytucjach rynku pracy, Akademickie Biuro Karier to jednostka działająca na rzecz aktywizacji zawodowej studentów i absolwentów szkoły wyższej, prowadzona przez szkołę wyższą lub organizację studencką, do zadań której należy w szczególności:

1. dostarczanie studentom i absolwentom informacji o rynku pracy i możliwościach podnoszenia kwalifikacji zawodowych,

2. zbieranie, klasyfikowanie i udostępnianie ofert pracy, staży i praktyk zawodowych,

3. prowadzenie bazy danych studentów i absolwentów uczelni zainteresowanych znalezieniem pracy,

4. pomoc pracodawcom w pozyskiwaniu odpowiednich kandydatów na wolne miejsca pracy oraz staże zawodowe,

5. pomoc studentom $\mathrm{w}$ aktywnym poszukiwaniu pracy. ${ }^{14}$

Do tych podstawowych zadań stojących przed Biurami Karier należy dołączyć jeszcze jedno - wsparcie. Biura Karier muszą być instytucjami, gdzie każdy student uzyska pomoc z zakresu poruszania się po rynku pracy. Nawet te biura, które nie zatrudniają doradców zawodowych, mogą takiego wsparcia udzielić, choćby poprzez wskazanie, gdzie z usług doradcy możemy skorzystać, gdzie szukać pomocy. To centrum wiedzy zawodoznawczej dla studentów, to sieć kontaktów, to przede wszystkim niezwykle ważny przystanek podczas planowania swojej drogi zawodowej.

Rolą biur karier jest przede wszystkim przedstawienie możliwości pracy ze względu na wykorzystanie posiadanych umiejętności - w jakich branżach są one cenione, jak należy je poszerzać i doskonalić, jakie braki należy uzupełnić, w jaki sposób dobierać przedmioty na studiach, kursy i innego rodzaju zajęcia, by zwiększyć swoje szanse zatrudnienia. Wybór ścieżki kariery staje się wtedy mniej przypadkowy, a przejście

\footnotetext{
14 Strona internetowa www.biura-karier.net, stan na: 14.04.2010.
} 
od roli studenta do roli pracownika płynne i mniej zaskakujące. Znacząco skraca się wówczas okres poszukiwania pracy, dlatego, że osoby korzystające $\mathrm{z}$ doradztwa zawodowego (jak i innych usług biur karier) zaczynają szukać pracy wcześniej i są do tego lepiej przygotowane chociażby poprzez fakt, że otrzymują informację, w jaki sposób poszukiwać pracy i jak takie poszukiwania zaplanować. ${ }^{15}$

Potrzeba istnienia Biur Karier wynika z kilku aspektów. Rokrocznie zwiększa się liczba osób kończących szkoły wyższe. Młodym ludziom opuszczającym mury uczelni, bardzo często brakuje orientacji odnośnie rynku pracy, wymagań stawianych przez pracodawców potencjalnym pracownikom, jak również sposobów szukania pracy oraz autoprezentacji w trakcie rozmowy kwalifikacyjnej z pracodawcą. Tę wiedzę dostarczają absolwentom właśnie doradcy zawodowi zatrudnieni w Biurach Karier. Kolejna przyczyna wynika ze zmian, jakie nastapiły w naszym kraju w ciagu kilku ostatnich lat. Otóż, coraz bardziej wzrasta potrzeba korzystania z profesjonalnych usług doradczych oraz usług związanych z rekrutacją wśród studentów realizowanych na rzecz pracodawców.

Biura Karier są także jednostkami przygotowującymi innych pracowników uczelni wyższej do prowadzenia zajęć związanych z zagadnieniami rynku pracy lub też pracownicy biur sami takie zajęcia prowadzą w formie kilkunasto- lub kilkudziesięciogodzinnych bloków. Należy zauważyć, iż biura aktywnie działają na rzecz włączenia zagadnień związanych z poszukiwaniem zatrudnienia do programów nauczania na poszczególnych kierunkach. Wiąże się to $\mathrm{w}$ dalszym ciągu $\mathrm{z}$ nowym spojrzeniem na szkoły wyższe. Przestały być one wyłącznie instytucjami zapewniającymi wiedzę teoretyczna, a stają się miejscami, gdzie oprócz wykształcenia należy także zapewnić umiejętności wykorzystania nabytej wiedzy w dalszym życiu zawodowym oraz płynne przejście od studiowania do kolejnego etapu, jakim jest praca zawodowa. ${ }^{16}$

Biura Karier (Careers Services) są jednostkami organizacyjnymi szkół wyższych. Pierwsze biura powstały w Wielkiej Brytanii jeszcze

15 Por. D. Jajtner, Biura karier - po co i dla kogo istniejq?, „Pedagogika Pracy” 2006 nr 49, s. 95.

16 Tamże, s. 97. 
na początku XX wieku. Stanowiły one element poradnictwa psychologicznego dla młodzieży, zwłaszcza tej pobierającej nauki w szkołach z internatem, w oderwaniu od domu rodzinnego. Biura Karier w Wielkiej Brytanii aktualnie kładą duży nacisk na poradnictwo, pomoc w zakresie określenia predyspozycji i zainteresowań kandydatów oraz właściwego zaplanowania dalszej drogi życiowej i zawodowej studentów. Ważnym elementem działalności jest odniesienie świadczonych usług w kierunku jednej grupy odbiorców, a mianowicie tylko studentów. Studenci uzyskują pomoc doradczą (doradztwo zawodowe) oraz informacyjną (np. związaną z rynkiem pracy). Przez wiele lat funkcjonowania brytyjskie Biura Karier udoskonalały metody pracy ze studentami, wypracowały standardy i procedury związane z prowadzoną działalnością. Dlatego też brytyjskie Biura Karier uznawane są za prekursorów i propagatorów idei funkcjonowania Biur Karier w Europie i na świecie.

W Polsce pierwsze Biuro Karier zostało utworzone w 1993 roku na Uniwersytecie im. Mikołaja Kopernika w Toruniu. Biuro to powstało dzięki uporowi i wsparciu merytorycznemu Johna C. Franksa, Dyrektora Biura Karier na Uniwersytecie w Hull (Wielka Brytania). W 1997 roku, w ramach programu TEMPUS Phare powstało kolejnych osiem biur na największych uczelniach w Polsce: Uniwersytecie im. Adama Mickiewicza w Poznaniu, Szkole Wyższej Gospodarstwa Wiejskiego (SGGW Warszawa), Politechnice Śląskiej (Gliwice), Akademii Ekonomicznej w Katowicach, Politechnice Świętokrzyskiej (Kielce), Politechnice Krakowskiej, Uniwersytecie Marii Curie-Skłodowskiej (UMCS Lublin), Politechnice Wrocławskiej i Uniwersytecie Wrocławskim. Ostatnie dwie uczelnie podpisały umowę o współpracy, na mocy której utworzone zostało jedno biuro, którego zadaniem była zawodowa promocja studentów i absolwentów obu tych uczelni. W 1998 roku te osiem biur wspólnie z Biurem Karier UMK w Toruniu powołały do życia Ogólnopolską Sieć Biur Karier (OSBK) i stało się jednocześnie Konwentem OSBK jako członkowie - założyciele sieci. W latach kolejnych na innych uczelniach, już nie tylko państwowych, ale również prywatnych, zaczęły powstawać Biura Karier. Część z nich, spełniając pewne określone założenia programowe i logistyczne, wstąpiła do Ogólnopolskiej Sieci Biur Karier. 
Biura Karier spełniają wiele funkcji:

1. Są biurami obsługi studentów: informują, doradzają, wspierają w wyborze drogi zawodowej;

2. Są centrami informacji: gromadzą oraz upowszechniają informacje o rynku pracy, możliwościach podnoszenia kwalifikacji zawodowych, tworzą bazy danych;

3. Są ośrodkami zatrudnienia: pozyskują oferty pracy oraz propozycje praktyk i staży. ${ }^{17}$

Misją prowadzonej działalności jest udzielenie wszechstronnego wsparcia studentom i absolwentom $\mathrm{w}$ wejściu i utrzymaniu się na rynku pracy. Misja ta realizowana jest poprzez następujące cele:

1. Prowadzenie doradztwa zawodowego indywidualnego i grupowego, kształtującego niezbędne umiejętności studentów i absolwentów w poszukiwaniu pracy.

2. Nawiązywanie i utrzymywanie kontaktów z pracodawcami - pozyskiwanie ofert pracy, praktyk, staży zawodowych dla studentów i absolwentów.

3. Współpraca z władzami uczelni, władzami miasta i województwa, organizacjami pracodawców, organizacjami studenckimi, Ministerstwami: Pracy i Polityki Społecznej, Gospodarki, w celu organizowania wspólnych przedsięwzięć i propagowania inicjatyw adresowanych do studentów i absolwentów szukających pracy.

4. Gromadzenie informacji na temat rynku pracy, jego wymagań i tendencji. ${ }^{18}$ Akademickie Biuro Karier w dużym zakresie może przyczynić się do zwiększenia możliwości i wskaźników zatrudnienia absolwentów uczelni. Zainteresowanie na rynku pracy zatrudnieniem studentów i absolwentów danej placówki, wzmacnia jej wartość na rynku edukacyjnym, a to wiąże się ze wzrostem liczby kształcących się w jej murach. ${ }^{19}$ Dzięki

\footnotetext{
17 Por. R. Lamb, Poradnictwo zawodowe w zarysie, „Zeszyt informacyjno-metodyczny doradcy zawodowego" $1998 \mathrm{nr}$ 9, s. 13.

18 Tamże, s. 9-10.

19 Bardzo często jednym z pierwszych pytań, które stawia absolwent szkoły średniej przy wyborze uczelni, dotyczy możliwości zatrudnienia absolwentów oraz czy łatwo uzyskać zatrudnieni po ukończeniu danej uczelni.
} 
istnieniu Akademickiego Biura Karier można lepiej promować uczelnie i dzięki temu uzyskiwać wyższe miejsca w rankingach. Im skuteczniej i szerzej działa biuro, tym więcej informacji o placówce przedostaje się na rynek, budując wizerunek uczelni dynamicznej i dbającej o studenta i absolwenta.

\section{DORADCA ZAWODOWY WOBEC PROBLEMÓW STUDENTÓW I ABSOLWENTÓW}

Doradztwo zawodowe to wymóg czasu wynikający z wejścia Polski do Unii Europejskiej, przemian gospodarczych i rosnącego bezrobocia. Jest ono procesem pomagania ludziom w osiagnięciu lepszego rozumienia siebie samego w odniesieniu do wyboru właściwej szkoły, właściwego dostosowania zawodowego. Jego celem jest zapoznanie osoby poszukującej z: jej możliwościami i zainteresowaniami; możliwościami w odniesieniu do rynku pracy; warunkami ekonomicznymi; przeciwwskazaniami i szczególnymi wymaganiami; rodzajami poszukiwania pracy; umiejętnościami kontaktowania się z pracodawcami. ${ }^{20}$

We współczesnym świecie coraz trudniej o stabilne zatrudnienie oraz miarową karierę zawodową z licznymi awansami, wysługą lat oraz dostępem do określonych świadczeń. Czasy równorzędności karier, a więc gwarantujące taką samą karierę ludziom o tych samych zdolnościach, bezpowrotnie minęły. Obecnie nawet nie mówi się już o karierze zawodowej polegającej na wspinaniu się po poszczególnych szczeblach tej kariery, gdyż droga życia współczesnego człowieka jest zbyt niepewna i nie gromadzi ona zasług czy uprawnień, lecz ulega ciagłym zmianom. Globalizacja sprawiła, iż rynek pracy docenia przede wszystkim elastyczność, kreatywność i szybkość przestawiania się na nowy styl działania. Świat jest nieprzewidywalny i postrzegany jest jako świat wielorakich kryzysów: tradycyjnych systemów kontroli i władzy, pracy

${ }^{20}$ A. Bańka, Zawodoznawstwo, doradztwo zawodowe, pośrednictwo pracy, Poznań 1995, s. 23. 
i niekontrolowanego wzrostu bezrobocia, życia społecznego i rodziny, zagubienie i utrat poczucia tożsamości. ${ }^{21}$

Planowanie kariery zawodowej to konieczność, przed jaką staje każdy młody człowiek. Praca powinna być nie tylko źródłem dochodu, ale także zawodowej satysfakcji wynikającej z rozwijania swoich pasji, realizowania zainteresowań i rozwoju osobistego. Podjęcie decyzji o kształceniu w szkołach różnego szczebla i wybór zawodu powinny być procesem decyzyjnym trwającym dłuższy czas. Rozwój zawodowy obejmuje całe życie człowieka, a aktualna sytuacja na rynku pracy stwarza konieczność dostosowywania własnych kwalifikacji zawodowych do istniejących ofert pracy.

Musimy sobie uświadomić, że wybór kierunku studiów, szczególnie wybór właściwy jest pierwszym krokiem niezwykle istotnym na tym etapie rozwoju. Nie wolno traktować studiów jako czasu na odwlekanie decyzji dotyczącej tego, czym w życiu dana jednostka chce się zajmować. To okres, który poświęcony na analizę własnych zainteresowań i porównanie ich z możliwościami zawodowymi, to czas na szeroki rozwój, na zdobywanie wiedzy. Planowe i przemyślane podejście do okresu studiowania pozwala na wieloaspektowy rozwój, np. poprzez zdobycie potrzebnej wiedzy we własnej uczelni oraz wyjazdy zagraniczne w ramach programów stypendialnych, umożliwiających zdobycie doświadczeń międzykulturowych, poznania zróżnicowania w podejściu do nauki, wymiany informacji. Studia to okres umożliwiający również zdobywanie doświadczenia $\mathrm{w}$ ramach programowych i ponadprogramowych praktyk oraz wolontariatu. Wielu młodych ludzi w tym okresie zdobywa nowe umiejętności, podnosi kwalifikacje poza formalnym trybem kształcenia. ${ }^{22}$

Dla większości młodych ludzi wolontariat jest przede wszystkim niesieniem pomocy innym ludziom. Podkreślają, że zdecydowanie nie jest sposobem na ułożenie sobie kariery zawodowej, nie oczekują niczego

${ }^{21}$ E. Jańczak-Obst, Inteligencja emocjonalna doradcy, [w:] B. Wojtasik, A. Kargulowa, (red.), Doradca - profesja, pasja, powołanie? ...? Materiaty ze Światowego Kongresu Poradnictwa Zawodowego, Warszawa 29-31 maja 2002, s. 189-202.

22 D. Pisula, Poradnictwo..., dz. cyt. s. 92. 
w zamian. Jest to bardzo dobra postawa świadcząca o bezinteresowności tych ludzi, potrzebie wypływającej prosto z serca. Ale uczestnictwo we wszelkich formach wolontariatu świadczy również o ich zaradności, potrzebie rozwoju i dojrzałości życiowej. To dowód, że osoba ma inicjatywę, dąży do swojego celu, chce się uczyć i nie czeka, aż ktoś inny weźmie jej los w swoje ręce; wolontariat jest informacją, że dana osoba jest otwarta na drugiego człowieka i prawdopodobnie będzie umieć dobrze współpracować w zespole. Wolontariat w życiorysie, zwłaszcza młodej osoby, dowodzi świadomości wymagań, jakie stawia dzisiejszy rynek pracy, i chęci zdobywania konkurencyjnego doświadczenia.

Wzmianka w CV na temat wolontariatu ma znaczenie szczególnie w przypadku osób, które nie mają jeszcze doświadczenia zawodowego. Pokazuje to, że człowiek jest aktywny i poszukuje ścieżki zawodowej dla siebie. Wolontariaty pozwalające na zdobycie merytorycznej wiedzy i umiejętności, takiej, której często nie można odnaleźć w fachowej literaturze. Wniosek jest jeden: wolontariusz, robiąc coś dobrego dla innych, przy okazji oddaje ważną przysługę samemu sobie. Specjaliści z branży personalnej są zgodni - wolontariusze są mile widzianymi kandydatami do pracy. Oczywiście nie jest to najważniejsze kryterium selekcji, ale taki punkt w życiorysie to zawsze olbrzymia zaleta.

Udział w projekcie wolontariackim ma dwojaki wpływ na jednostkę. Po pierwsze, pojawi się potrzeba bezinteresownej pomocy drugiemu człowiekowi, poczucia, że można dać coś od siebie innym. Po drugie, jest to na pewno możliwość samorealizacji w innych obszarach niż praca zawodowa. Praktyka pokazuje, że nie tylko zaoferowanie pomocy materialnej może być dla kogoś wartościowe, ale również to, co każdy może dać z siebie samego - zrozumienie, ciepłe słowo, swój czas i zainteresowanie drugą osobą.

Dla studentów i osób będących na początku drogi swej profesjonalnej kariery wolontariat jest sposobem na wpasowanie się w oczekiwania i wymagania rynku pracy, a jednocześnie na podążanie drogą własnych wartości. Przede wszystkim wolontariat pozwala zdobyć wiedzę i umiejętności, ale nie jest tak rygorystyczny, jak praca na etacie. Nie wymaga rezygnacji ze studiów, często umożliwia indywidualne ustalanie dni 
i wymiaru pracy. To, że zwykle wolontariat realizowany jest w zakresie i dziedzinie, którą wolontariusz się interesuje, sprawia, że praca wykonywana jest z zapałem, często okazuje się być prawdziwą pasją i wykonywana jest $\mathrm{z}$ dużym poświęceniem. Obecnie nie ma większych problemów z dobraniem działalności organizacji do zainteresowań i kierunku studiów wolontariusza.

Kariera zawodowa w obecnej rzeczywistości rozpoczyna się już na studiach. Nie są to tylko pierwsze doświadczenia zawodowe poprzez pracę dodatkową czy też praktyki. Uczestnictwo we wszelkich organizacjach młodzieżowych, kołach zainteresowań, konferencjach dają możliwość zdobycia pierwszych doświadczeń, wykazania się wiedzą i umiejętnościami, co może zaowocować dalszą kontynuacją. Dla tego okresu rozwoju charakterystyczna jest wiara, że wszystko można zrobić, nieszablonowe, pozbawione rutyny i schematyczności działanie, kreatywne podejście do rozwiązywania problemów. Praktyki i doświadczenia podczas studiów pozwalają na rozwinięcie umiejętności przełożenia wiedzy na praktykę. Zdobyte przez nich doświadczenia są dokumentowane i archiwizowane, a podejmowane formy dokształcania dobierane do wymagań stawianych przez rynek pracy. Osoby te płynnie przechodzą między edukacją i wejściem w życie zawodowe. ${ }^{23}$

Rola poradnictwa polega obecnie na udzieleniu pomocy jednostce w konstruowaniu przebiegu jej kariery zawodowej i rozumieniu jej jako „projektu życiowego", i to nie tylko w określonych fazach egzystencji, jak na przykład w okresie przejścia od nauki do życia zawodowego, lecz przez całe życie. ${ }^{24} \mathrm{~W}$ obecnym świecie proces doradczy jest - jak twierdzi A. Bańka - „tą formą praktyki doradczej, która polega na asystowaniu ludziom na wszystkich stadiach rozwoju (...) w rozwiązywaniu problemów będących konsekwencją podjęcia przez nich dobrowolnej decyzji życia, pracy lub nauki." 25

23 Tamże, s. 93.

24 Za B. J. Ertelt, Nowe trendy w poradnictwie zawodowym, [w:] Narodowe Centrum Zasobów Poradnictwa Zawodowego.

25 A. Bańka, Zawodoznawstwo, doradztwo zawodowe, pośrednictwo pracy, Poznań 2003, s. 23. 


\section{PODSUMOWANIE}

Zmiany zachodzące zarówno na świcie, jak i w naszym społeczeństwie, te gospodarcze i te bardziej mentalne mają istotny wpływ na doradztwo zawodowe i związane $\mathrm{z}$ nim procesy. W szczególności rynek pracy wyznacza nowe tendencje i wyzwania dla poradnictwa. Praca z nowymi grupami klientów, szybkie przyspieszenie gospodarcze, kryzysy, które również nie omijają naszego kraju - wszystkie te zjawiska są bardzo intensywne i wymagają odpowiednio przygotowanych specjalistów, którzy pomogą obywatelom w odnalezieniu się w nowej rzeczywistości. Przemiany w sektorze gospodarczym i na rynku pracy są tożsame z przemianami w sektorze usług doradczych. Powstawanie Szkolnych Ośrodków Kariery, Akademickich Biur Karier, rozwój prywatnych agenci zatrudnienia świadczących usługi z zakresu poradnictwa zawodowego. Współczesne doradztwo zawodowe powinno być procesem podporządkowanym koncepcjom kompleksowego rozwoju zawodowego człowieka w kontekście planowania kariery zawodowej w ciągu całego życia.

Zmienność otoczenia powoduje, iż w ciagu całego życia otwieraja i zamykają się przed jednostką nowe możliwości. Świadomie kierując swoimi wyborami edukacyjno-zawodowymi osoba jest w stanie bardziej efektywnie kierować swoim rozwojem i dążyć do większych osiągnięć. Im wcześniejszy okres, w którym jednostka rozpocznie planowanie i świadome kształtowanie swojego rozwoju edukacyjno-zawodowego tym więcej może osiągnąć w życiu. Zarówno nadmiar informacji jak i brak wiedzy jak korzystać z potencjalnych możliwości rodzi u osób planujących karierę potrzebę wsparcia przez doradców posiadających wiedzę i kompetencje w tym zakresie.

Doradztwo zawodowe musi w dzisiejszych czasach niejako poprowadzić jednostkę poprzez świat, udzielić jej wsparcia i pomocy. ${ }^{26} \mathrm{Nie}$ ulega wątpliwości, że rynek pracy będzie dalej ewoluował. Niestety nie wiemy, w jakim kierunku. Pewna staje się jednak konieczność rozwoju

${ }^{26}$ Por. D. Kukla, K. Kurek, Doradztwo w ponowoczesnym spoleczeństwie ryzyka, [w:] D. Kukla (red.), Wielowymiarowość poradnictwa w życiu człowieka, Warszawa 2009, s. 87. 
poradnictwa zawodowego, gdyż tylko dzięki niemu łatwiej będzie nam te zmiany zaakceptować, a może nawet wykorzystać. Aktualna sytuacja społeczno-ekonomiczna naszego kraju stawia przed ludźmi duże wyzwania. Podejmowane decyzje nabierają szczególnego znaczenia. Dotyczy to planowania przyszłej drogi zawodowej. W związku z pojawieniem się na rynku pracy problemu bezrobocia i wciąż rosnącym tempem życia, nikogo nie stać na przypadkowe wybory, zarówno ze względów ekonomicznych, jak i z uwagi na wysokie koszty emocjonalne.

Doradztwo zawodowe na rynku ogarniętym bezrobociem jest potrzebne i powinno się rozwijać. Ten rozwój wydaje się być nieunikniony jako trend wynikający z tego, że nowoczesne społeczeństwa funkcjonują w warunkach, gdzie popyt na wszelkie doradzanie, od finansów, ubezpieczeń po zawód i zatrudnienie włącznie, rośnie i takie profesje doradców mają bez wątpienia przyszłość.

Zdobycie pierwszej pracy wcale nie jest zadaniem łatwym, dlatego też koniecznej jest korzystanie z różnorodnych, dostępnych sposobów i metod jej poszukiwania, które dają szansę na powodzenie w tym zakresie. Obecnie coraz popularniejsze wśród studentów i absolwentów szkół wyższych staje się korzystanie z pomocy i szerokiego wachlarza usług świadczonych przez Akademickie Biura Karier.

\section{BIBLIOGRAFIA}

Bańka A., Zawodoznawstwo, doradztwo zawodowe, pośrednictwo pracy, Poznań 1995.

Bańka A., Poradnictwo transnacjonalne, Warszawa 2006.

Beck U., Społeczeństwo ryzyka - w drodze do innej nowoczesności, Warszawa 2004.

Eggert M., Doskonała kariera, Poznań 2004.

Ertelt B. J., Nowe trendy w poradnictwie zawodowym, [w:] Narodowe Centrum Zasobów Poradnictwa Zawodowego.

Fatyga B., Biała księga młodzieży polskiej. Diagnoza sytuacji młodych Polaków jako podstawa strategii państwa dla młodzieży, Warszawa 2004. 
Fitoussi J., Czas nowych nierówności, Kraków 2000.

Jan Paweł II, Laborem Exercens, Lublin 1986.

Jajtner D., Biura karier - po co i dla kogo istnieja?, „Pedagogika Pracy" $2006 \mathrm{nr} 49$.

Jańczak-Obst E., Inteligencja emocjonalna doradcy, [w:] B. Wojtasik, A. Kargulowa, (red.), Doradca - profesja, pasja, powołanie? Materiały ze Światowego Kongresu Poradnictwa Zawodowego, Warszawa 29 -31 maja 2002.

Kukla D., Kurek K., Doradztwo w ponowoczesnym spoleczeństwie ryzyka, [w:] D. Kukla (red.), Wielowymiarowość poradnictwa w życiu czlowieka, Warszawa 2009.

Lamb R., Poradnictwo zawodowe w zarysie, „Zeszyt informacyjnometodyczny doradcy zawodowego" $1998 \mathrm{nr} 9$.

Lelińska K., Znaczenie socjologicznych teorii wyboru zawodu w pracy doradcy zawodowego, [w:] H. Bednarczyk (red.), Pedagogika pracy. Doradztwo zawodowe, Radom 2002.

Mrozek M., Praca z klientem dorostym, Warszawa 2009.

Pisula D., Poradnictwo kariery przez całe życie, Warszawa 2009.

Strona internetowa www.praca.pl, stan na: 15.03.2010.

Strona internetowa www.biura-karier.net, stan na: 14.04.2010.

Walczak-Duraj D., Wartości i postawy młodzieży polskiej, Łódź 2009, t. II.

Wiatrowski Z., Podstawy pedagogiki pracy, Bydgoszcz 1994. 